DOI: https://doi.org/10.24127/ajpm.v10i4.4224

\title{
PISA PROBLEM SOLVING: THE INVESTIGATION OF STUDENT'S EXPERIENCE THROUGH DISTANCE LEARNING DURING PANDEMIC
}

\author{
Sapto Aji Nugroho', Christina Kartika Sari ${ }^{2 *}$ \\ 1,2* Mathematics Education, Universitas Muhammadiyah Surakarta, Indonesia \\ *Corresponding author. Jl. A. Yani, Mendungan, Pabelan, Kecamatan Kartasura, \\ Kabupaten Sukoharjo Jawa Tengah 57169 \\ E-mail: $\quad$ saptoajin9@gmail.com $^{1)}$ \\ $\underline{\text { christina.k.sari@ums.ac.id }}^{2 *}$
}

Received 14 September 2021; Received in revised form 02 December 2021; Accepted 28 December 2021

\begin{abstract}
This research aim to investigate the student's problem solving experience while carry out distance learning during pandemic covid-19 based on PISA question. Problems similar to PISA with the theme of hollow iron are used as a helping instrument to see how students' problem solving abilities are. In accordance with the PISA research, the subjects of this study were 8th graders of junior high school in Karanganyar Regency, Indonesia with an age range of 15-16 years. For advance, qualitative-descriptive research study was taken. In addition to tests, other auxiliary instruments are interview guidelines where the data obtained from the two instruments are compared so that the data obtained are truly valid. Subjects were selected by means of snowball sampling until the data obtained were considered sufficient by the key instrument, namely the researcher himself. Through data collection, data reduction, data presentation, conclusion drawing and verification, the results show that students with high abilities can identify problems well, formulate a settlement plan with simple procedures, execute plans in a coherent and clear manner, and re-examine the components involved. considered dubious. Students with medium abilities tend not to be careful in identifying information which results in discrepancies in the answers obtained. while students with low abilities find it difficult to solve non-routine problems and tend not to try to think of better solutions.
\end{abstract}

Keywords: PISA-like questions; Polya's theory; Problem solving skill.

\begin{abstract}
Abstrak
Soal serupa PISA dengan tema besi berongga dijadikan sebagai instrument bantu untuk melihat bagaimana kemampuan pemecahan masalah siswa. Sesuai dengan penelitian PISA, subjek penelitian ini merupakan siswa kelas 8 SMP di Kabupaten Karanganyar Indonesia dengan umur berada pada interval 15-16 tahun. Selain tes, instrumen terdapat pedoman wawancara dimana data yang diperoleh dari kedua instrumen dibandingkan sehingga data yang diperoleh benar-benar absah. Pemilihan subjek dengan cara snowball sampling sampai data yang diperoleh dianggap cukup oleh instrument kunci yaitu peneliti sendiri. Melalui pengumpulan data, reduksi data, penyajian data, penarikan kesimpulan dan verifikasi diperoleh hasil yang menunjukkan bahwa siswa dengan kemampuan tinggi dapat mengidentifikasi masalah dengan baik, merumuskan rencana penyelesaian dengan prosedur yang sederhana, eksekusi rencana dilakukan secara runtut dan jelas, dan memeriksa kembali komponen yang dianggap meragukan. Siswa dengan kemampuan sedang cenderung tidak teliti dalam mengidentifikasi informasi yang berakibat pada ketidaksesuaian jawaban yang diperoleh. sedangkan siswa dengan kemampuan rendah sulit untuk memecahkan permasalahan non-rutin dan cenderung tidak berusaha untuk memikirkan solusi yang lebih baik.
\end{abstract}

Kata kunci: Kemampuan pemecahan masalah; soal serupa PISA; teori Polya.

This is an open access article under the Creative Commons Attribution 4.0 International License 
DOI: https://doi.org/10.24127/ajpm.v10i4.4224

\section{INTRODUCTION}

The implementation of distance learning has started since the beginning of 2020 (A Hendriyanto et al., 2021). This means that it has been more than a year of students attending school without feeling the real school environment. This time is the beginning of the year of learning where students who graduate from elementary school will continue their education to the firstyear school and 7th graders rise one level above it. 8th graders in the current 2021/2022 school year have taken a junior high school education conducted online. This makes students need to adapt more quickly, so that there are different, unique, and worthy learning experiences. Student's experience are important to researched

Learning that is done directly with learning done online certainly has a different effect on student understanding. Some research-revealed that online learning is still not maximal, so that the learning that occurs cannot achieve the goal as expected (Delgado \& Salmerón, 2021; Agus Hendriyanto et al., 2021; Putz et al., 2020).

In Indonesia, distance learning is still the main alternative choice to minimize the transmission of the covid19 virus in the student environment (Dwivedi et al., 2020). On the other hand, if distance learning is still implemented continuously, it will certainly reduce the quality of learners. The reality related to the learning achievement of Indonesian students before the pandemic is still categorized as low, including in the field of mathematics.

The results of the last Programme for International Student Assessment (PISA) international survey conducted in 2018 showed that $71 \%$ of Indonesian students did not achieve the minimum level of mathematical competence. In the PISA 2018 study, Indonesian students' ability in mathematics achieved an average score of 379 . The average score ranked Indonesia 72nd out of 78 countries that took the PISA survey, Indonesia was far below Thailand and Uruguay. This shows that there are still many Indonesian students struggling in dealing with situations that require problem-solving skills using mathematics (Suciati et al., 2020).

PISA is an international study of the reading literacy, mathematics and science of 15-year-old school students (Ishizaka \& Resce, 2021). The study was conducted every three years since 2000 and last year in 2018. It should be implemented again in 2021, but with the global pandemic conditions occurring, it is possible that the study will be canceled and will be implemented if global conditions are possible.

Ideally, there will be an increase in the learning achievement of Indonesian students during the upcoming PISA study. This achievement reveal to student's mathematic problem solving. However, the field data shows otherwise. Every student has their own problem through upcoming technology era. Problem solving on mathematic still become homework for teacher, even the experienced one. It is very important to know student's problem to enhance their solving ability.

As stated above, the learning during this pandemic is not considered to be running optimally. Of course, this is a concern for educators and stakeholders in the field of education. These concerns are related to the problem-solving ability that learners have. It is not certain that the learning achievements that will be obtained during the upcoming PISA study will increase from previous studies. 
DOI: https://doi.org/10.24127/ajpm.v10i4.4224

This is where this research needs to be done as an early detection of students' problem-solving abilities in solving PISA-type problems. The stages of problem solving that will be used are stages according to Polya consisting of understanding the problem, devising a plan, carrying out the plan, looking back (Tohir et al., 2020). Table 1 shows the Polya Problem Solving stages could be taken to reach data research.

Table 1. Polya problem solving stages

\begin{tabular}{ll}
\hline \multicolumn{1}{c}{ Stages } & \multicolumn{2}{c}{ Description } \\
\hline Understanding the Problem & $\begin{array}{l}\text { Stating problems with your own words, finding } \\
\text { information }\end{array}$ \\
$\begin{array}{l}\text { Wevising a plan } \\
\text { Carrying Out the Plan }\end{array}$ & $\begin{array}{l}\text { Carry out the plan that has been made } \\
\text { Leoking back }\end{array}$ \\
\hline
\end{tabular}

The advantages of using polya theory is that it can be used as a medium of practice for learners to think systematically and structured (Laulin, 2020). In addition, learners can also train their ability in solving problems objectively (Zamnah et al., 2021).

The study of students' ability to solve PISA problems based on Polya theory has been done before. However, the field was not in a pandemic period. This is what distinguishes this study from other researchers. Some researchers have revealed that learning in this pandemic period is very influential on the level of problemsolving skills of students. The influence in question is not a positive influence but a negative influence. So, this study try to investigate of student's experience through distance learning during pandemic by PISA problem solving. It hope could be reference for teacher in order to enhance better education.

\section{RESEARCH METHOD}

The study uses 24 students in aged between 15-16 years. It was conducted in middle school at Karanganyar Regency, which randomly picked. The chosen schools has familiar about how the problem-solving use as learning method in pandemic period, which refer to PISA. Researchers as the main instrument and by using assistive instruments in the form of PISA-like tests and interview guidelines, this qualitative descriptive research uses data retrieval events, namely tests, interviews, and documentation.

Tests and interviews are used as a way to obtain data on students' problemsolving abilities where the tools used meet both valid and reliable criteria. While documentation is used as a way to obtain student repeat value data. The data is further analyzed to determine the student's problem solving ability categories into three categories, such as: high, medium, and low.

Any kind of data compared so that the data obtained is completely valid. In addition, triangulation methods are also done by encoding the data obtained from each subject. Subjects are selected by using snowball sampling techniques and stop until the data is actually deemed sufficient.

Analysis data related student's test and interview. Along with data collection, interpretation carried out with the intention of sharpening the focus of observation and deepening problems relevant to the subject matter 
being studied. It is very important for researchers to make focused observations of the problems studied. Then, work in systematically explain data and ensure prostheses, hypotheses, concepts or patterns that have been built based on students experience data. It analyzed by Polya stage as described in Table 1. Researchers complete the existing data if they find the data that has been presented less in accordance with the focus of the study. So, it could be deep and could be understand by reader.

\section{RESEARCH RESULT}

In this study, students were divided into three categories, namely high, medium, and low. Categorization uses value data from daily reassessments of previous material provided by teachers. Referring to the average and standard deviation obtained, students can be grouped as Table 3.

Table 3. The Classification of Students' Problem-Solving Ability

\begin{tabular}{ccccc}
\hline No & Interval & Category & Limitation & Student \\
\hline 1 & $X \geq \bar{X}+0.5 \sigma$ & High & $X \geq 80.70$ & 4 \\
2 & $\bar{X}-0.5 \sigma<X<\bar{X}+0.5 \sigma$ & Medium & $72.22<X<<80.70$ & 7 \\
3 & $X \leq \bar{X}-0.5 \sigma$ & Low & $X \leq 72.22$ & 13 \\
\hline
\end{tabular}

With: $X=$ Score which obtained

$\bar{X}=$ Average of sample

$\sigma=$ Deviation standard of sample

Teacher give students PISA questions on class. Then, the student's answer corrected carefully and give them grade level in before categorized into three classification such as Table 3. Furthermore, from each category selected two students based on input from teachers with student backgrounds that are easy to interact with and have good communication skills to be interviewed related to the results of their work, as a follow-up to the excavation of data related to problem-solving skills. The questions used in this study as in Figure 1.

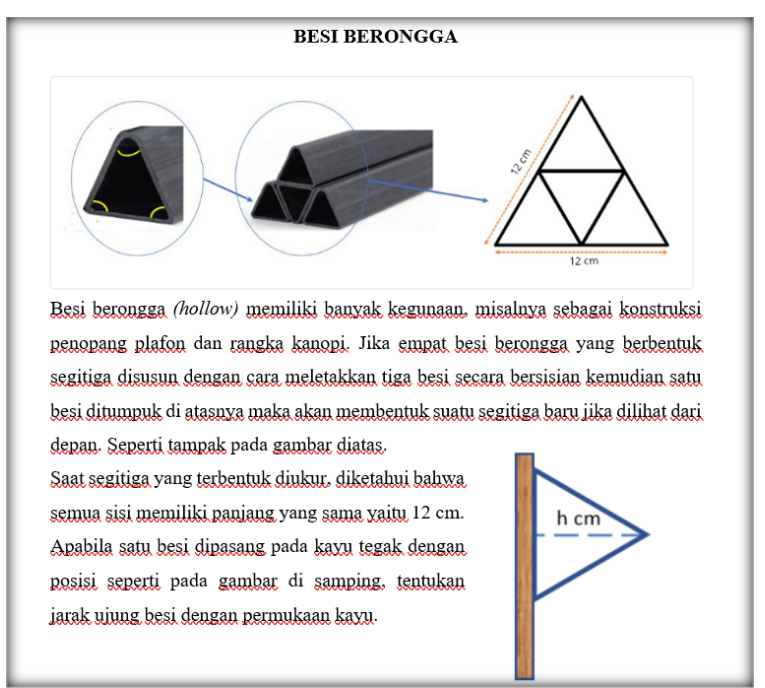

Figure 1. PISA Question on Space and Shape Topic 


\section{The Analysis of Students with High Category}

The ability of students with high categories (R1) in understanding the problem can be said to be very good, this is shown with the accuracy of all subjects high in identifying existing information. Information related to the known and questioned components can be clearly written (Figure 2).

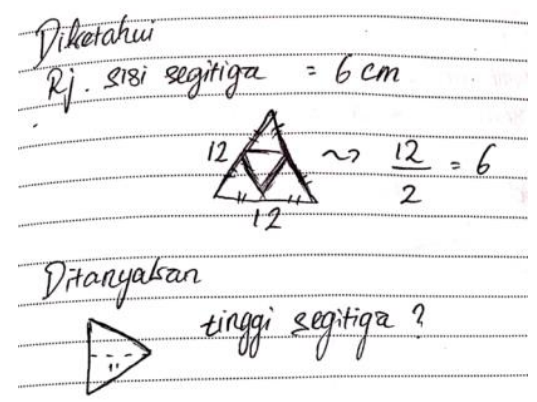

Figure 2. R1 Answer on Understanding the Problem Stage

Based on Figure 2, R1 can know that iron has an equilateral triangle shape with a side length of $6 \mathrm{~cm}$ as written in the "Known" section. Then
$\mathrm{R} 1$ is also able to state that what is asked is the height of the triangle as written in the "Asked" section. The answer shows that R1 really understands the problem. This is in accordance with the results of the interview with R1 when the researcher asked "can you explain the information related to this first question?".

R1's answer to the question corresponds to what he wrote on the answer sheet. Here is the R1"answer from this image (pointing to figure A1), all three angles have the same large, then equilateral triangle-shaped iron. When the equilateral triangle is stacked like this (pointing to figure A3), the result is also an equilateral triangle. Because it is known that this (pointing to the side of the triangle in figure A3) is $12 \mathrm{~cm}$ long, then each iron has a side of $6 \mathrm{~cm}$. Then this (pointing to figure A4) is the same height of the triangle asked". Look at Figure 3 for the component support detail.

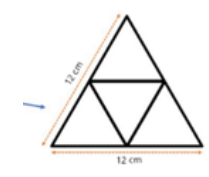

A3

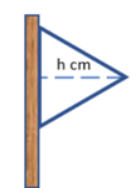

A4

A2

Figure 3. Interview Support Component on R1

From the results of the interview with R1, it is clear that R1's ability to understand the problem is very good. The R1 answer sheet and the interview results show the same results, meaning that what R1 writes is really based on its ability. Overall, the ability of high students in understanding problems is very well-known, they not only write on the answer sheet but are able to explain well through interviews,

The devising stage of a plan or problem-solving planning is the stage after students understand the problem. In planning problem solver, highly capable students use the concept of the Pythagorean. The Student writes the plan on Figure 4.

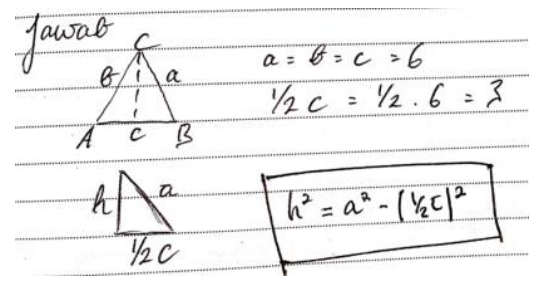

Figure 4. R1 Answer on devising a plan stage 
In Figure 4, R1 redraws the equilateral triangle and labels each corner with the $\mathrm{ABC}$ label, and each side is labeled $a, b, c$.Then $\mathrm{R} 1$ writes the Pythagorean formula that is adjusted to the label it has written. First, R1 writes the Pythagorean formula in general, then lowers it to determine the height of the triangle. In addition, R1 also describes the length of each side by writing $a=b=c=6$.

\section{$\mathrm{P}$ : How do you solve this question?}

$\mathrm{R} 1$ : This is the equilateral triangle, and the questioned height. For example, this is a, this is $b$, this is $c$ and this is $h$ (pointing the sides of the triangle), well, this is right (pointing the half of the triangle) forming a right triangle. So you can use the Pythagorean theorem. This side (pointing to the triangular base) is $3 \mathrm{~cm}$ long, and this (pointing to the oblique side) is 6 , well what this is looking for (pointing to the height of the triangle). So $h^{2}=6^{2}-3^{2}$

Based on the result interview, it is known that R1 planned to solve the problem well using the Pythagorean theorem. Between the answer sheet and the interview, the same result that R1 plans to solve the problem in the first problem using the Pythagorean theorem is shown. This is also done by other high students.

Carrying out the plan is an execution of what the previous stage was. In subtitling known information into the formula used, R1 illustrates several images of triangles: equilateral triangles and right triangles. In addition, R1 also labels certain parts (Figure 5).

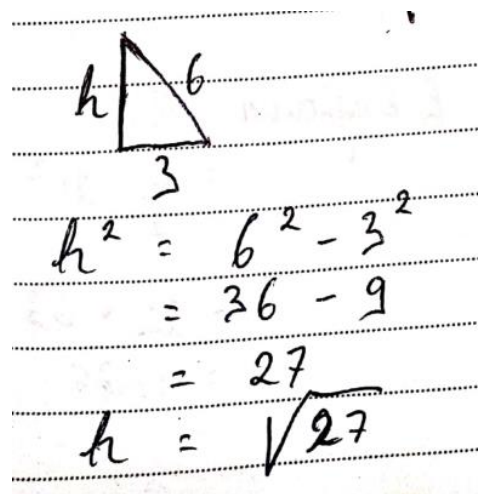

Figure 5. R1 answer on carrying out the plan stages

In Figure 5, R1 can identify that the oblique side of the right triangle is obtained from the length of the equilateral triangle side. In addition, R1 illustrates the right triangle to show that the problem to be answered is the height of the triangle or the front side of the triangle (h). Using the Pythagorean theorem (R1) he can discover $h=$ $\sqrt{27}$ that. During the interview, R1 explained smoothly related to the computing process carried out. Based on this, it can be said that R1 is able to carry out the carrying out the plan well.

The looking back stage is the activity of re-examining what has been done. Of course, this stage cannot be identified just by looking at the answer sheet but can be identified during the interview. R1 states that the process of rechecking is carried out only in the computing section. Related to data and information on the problem is not checked again.

\section{The Analysis of Students with Medium Category}

Students with the ability are not able to understand the problem well. Students with medium ability (R2) understand that the hollow iron arrangement that exists in the matter of forming an equilateral triangle with a side length of $12 \mathrm{~cm}$. But R3 does not 
realize that the triangle formed is an arrangement of four irons, "oh yes, there are four, I think this is just a line" said R2.

$\mathrm{R} 2$ is able to identify that what must be sought from the problem is the height of the triangle. Therefore, on the answer sheet R3 writes the question to be sought "height triangle?".

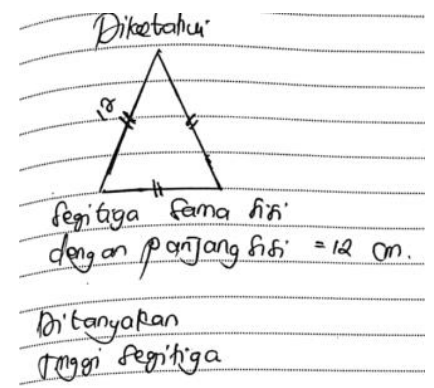

Figure 6 R2 answer on understanding the problem stage

Some important things are obtained through interview activities as a supporter of the R2 answer as in Figure 6. First, when reading the R2 problem, one does not pay attention to the iron image but immediately focused on the visual image of the triangle formed. Second, R2 does not read the problem as a whole, so it concludes the discrepancy of the information that exists with what it understands. From the results of the answer sheet and interview, it can be concluded that students with medium ability are not able to carry out the understanding stage of the problem properly.

When viewed from the standpoint of mathematical understanding, R2 understands that to solve problems in the first problem using the Pythagorean theorem. This was also confirmed by him "the triangle is equilateral, and the questioned height of the facet (while pointing to the tall image of the triangle) means that the triangle formed after being drawn the high line is a right triangle so that to find its height can be done with the Pythagorean formula". On the answer sheet R2 does not write the Pythagorean formula, but the calculations performed lead to the Pythagorean theorem.

The planning done by $\mathrm{R} 2$ can be said to be quite good if you look at the explanation during the interview. $\mathrm{R} 2$ is able to analyze how to solve existing problems.

The implementation of what has been planned at the devising stage of a plan is appropriate. At this stage of carrying out the plan, R2 performs computation based on information and plans that have been understood before. If you look at the calculations and adjust to the understanding of $\mathrm{R} 2$ at an earlier stage, $\mathrm{R} 2$ can perform computing well and precisely. But back again to the previous conclusion that the misconception that occurred at the understanding stage of the problem affects the solution of the problem at a later stage.

To determine the height of the triangle begins by dividing the two sides of the triangle. R3 looking for the height of the triangle by reducing the $\frac{12}{2}=6$ oblique side of the triangle with the back side of the triangle. It was done in accordance with the Pythagorean theorem $t=\sqrt{12^{2}-6^{2}}$. Look at the Figure 7.

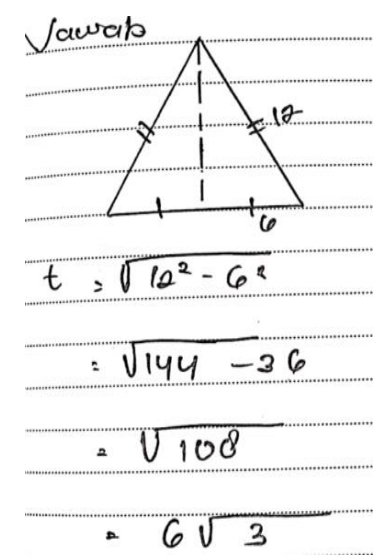

Figure 7. R2 answer on plan stage 
DOI: https://doi.org/10.24127/ajpm.v10i4.4224

In this case, $\mathrm{R} 2$ does not check the answers obtained because it already feels confident and the computation done has been found. "There is no need to check anymore, for this is obvious, and the calculation is also easy."

\section{The Analysis of Students with Low Category}

When working on problems, students with low ability are occasionally not understanding the problem first. On the answer sheet they only redraw the triangles that are on the problem. When interviewed, the lowability student (R3) said that "it's hard, so I just drew the triangle". Then another student (R3) said "I don't know how to look for the area of a curved triangle like this (pointing at the ceramic area outside the circle), so I just re-spread and write the circumference of the circle".

\section{DISCUSSION}

In students with high ability, they are able to go through all four stages of Polya as well. At the understanding the problem stage, students with high ability simply read the problem once by marking the parts that are considered important, and then they write down the information and questions referred to in the problem. At the devising a plan stage, students with high ability always advance in writing the formula to be used, and they always write the stages of completion well. At the carrying out the plan stage, students with high ability use formulas that have been written before and do computing well until the final result is obtained. At the looking back stage, students with high ability reexamine what they have written before they write a conclusion. Re-checking the answer aims to make sure that the answer that has been written is correct.
This is to minimize miscalculation so that conclusions can be drawn according to calculations.

Students who are mathematically capable by Widodo et al., (2020) are described as students who are able to analyze information and things needed in questions, including determining what is known and unknown, able to solve problems correctly, including explaining the steps of solving problems verbally. In addition, the results of this study are also in accordance with the results of research from Herayanti et al., (2020) which states that highly capable students have a good category in problem solving.

In students with medium ability, the problem understanding stage is not completely well-done. Students with the ability not to do analysis in advance are provided so that the information obtained is not accurate. Then at the devising stage of a plan students with the ability to plan the steps of completion well, namely by planning what formula to be used. In the last stage, namely looking back, students with the ability are not used to doublechecking the results of the answers they have written. This can lead to lack of certainty in the final answer, where students should double-check their answers because the student's willingness to solve problems is an indicator of students with high mathematical ability and not only based on the belief of those who believe that the answer that they wrote are correct.

In line with the results of this study, Tong et al., (2020) argue that students are capable of being said to be sufficient in problem solving because the subject mentions what is known from the problem even though it does not write the answer on the answer sheet. In addition, Runnalls \& Hong, 
(2020) describes students with medium mathematical ability are students who have the ability to generate mathematical information from questions and sometimes have misconceptions when re-explaining the steps in solving problems. The ability to produce information and the misconceptions in the problem-solving step is what often causes students to fail to connect the information understood. Therefore, in the problem solving stages, students with the ability often have difficulty in making and implementing the right plan in solving problems.

In students with low ability, they are not able to understand the problem well, so with its limitations they cannot solve the existing problems. From these results, certainly cannot be identified the next stage. In-depth interviews with low-skilled subjects showed that they had difficulty learning math subjects. Many students are unsure of the process or the answers they give, even though confidence has a great effect on solving problems.

Low-skilled students are 1) students who have low computing ability, 2) are unable to state what is known and asked in the question by using their own sentences and 3) tend to forget the concepts needed in answering questions (Pradita et al., 2021). In addition, the results of this study are also in accordance with research from Purnama et al., (2021) which states lowskilled students have a category of lack in problem solving because low-skilled subjects just read problems. The advantage of this research is that it has a wide sample variation, where there are 24 students from different schools, so it is strong as a benchmark. While this research is limited to 3 categories, the uniqueness of students outside these categories is not analyzed.

Mathematic problem solving's ability is very important, while it is hard enough to control it during distance learning occurred. Nevertheless, mathematical problem solving is crucial approach for daily live thinking which enables students to enhance high thinking skills and positive attitudes (Mairing, 2017). Whereas, we need as many experience reference conducted learning, this research can be proper reference for practitioners in helping students related to mathematical problem solving based on both distance learning and direct learning.

This study has been found that student's experiences during PPKM have an impact on problem solving abilities. It shown that problem solving ability is very important thing to enhance mathematical thinking of student. In this case, this study support many teacher as support decision to teach .

The resulting impact contributes to teachers in providing more creative and varied learning options during PPKM (Tohir et al., 2020). In addition, it becomes a great reference for broader research in the future. It ensures that problem solving needs to be emphasized for students in this age.

\section{CONCLUSIONS}

Overall, refer to this study aim, it could be understand that student problem solving ability need to emphasized to built wide experience. Students with high ability are only a few people, in general, the class is dominated by students with moderate and low abilities. Low PISA score results according to field conditions. It should be of concern to both parties that there needs to be concrete efforts to 
improve the mathematical abilities of students. Efforts that will be made to improve the mathematical ability of students must cover all aspects of learning, both learning models, learning resources, and other components.

Through this study, there is some suggestion occurred such as: researchers should consider all subjects as material for analysis so that the results are deeper and more complex. And research must involve multiple levels to be more useful.

\section{REFERENCES}

Delgado, P., \& Salmerón, L. (2021). The inattentive on-screen reading: Reading medium affects attention and reading comprehension under time pressure. Learning and Instruction, 71(August 2020). https://doi.org/10.1016/j.learninstr uc.2020.101396

Dwivedi, Y. K., Hughes, D. L., Coombs, C., Constantiou, I., Duan, Y., Edwards, J. S., Gupta, B., Lal, B., Misra, S., Prashant, P., Raman, R., Rana, N. P., Sharma, S. K., \& Upadhyay, N. (2020). Impact of COVID-19 pandemic on information management research and practice: Transforming education, work and life. International Journal of Information Management, 55(July), 102211. https://doi.org/10.1016/j.ijinfomgt. 2020.102211

Hendriyanto, A, Kusmayadi, T. A., \& Fitriana, L. (2021). Geometric Thinking Ability for Prospective Mathematics Teachers in Solving Ethnomathematics Problem. IOP Conference Series: Earth and Environmental Science, 1808. https://doi.org/10.1088/17426596/1808/1/012040
Hendriyanto, Agus, Kusmayadi, T. A., \& Fitriana, L. (2021). What are the type of learning media innovation needed to support distance learning? AKSIOMA: Jurnal Program Studi Pendidikan Matematika, 10(2), 1043-1052.

Herayanti, L., Widodo, W., Susantini, E., \& Gunawan, G. (2020). The effectiveness of blended learning model based on inquiry collaborative tutorial toward students' problem-solving skills in physics. Journal for the Education of Gifted Young Scientists, 8(3), 959-972.

https://doi.org/10.17478/JEGYS.67 5819

Ishizaka, A., \& Resce, G. (2021). BestWorst PROMETHEE method for evaluating school performance in the OECD's PISA project. SocioEconomic Planning Sciences, 73(January 2020), 100799. https://doi.org/10.1016/j.seps.2020.1 00799

Laulin, L. (2020). A martingale approach for Pólya urn processes. Electronic Communications in Probability, 25(39), 1-13. https://doi.org/10.1214/20-ECP321

Mairing, J. P. (2017). Students' Abilities To Solve Mathematical Problems According To Accreditation Levels. International Journal of Education, $10(1)$, https://doi.org/10.17509/ije.v10i1.69 02

Pradita, D. A. R., Maswar, M., Tohir, M., Junaidi, J., \& Hadiyansah, D. N. (2021). Analysis of Reflective Student Analogy Reasoning in Solving Geometry Problems. Journal of Physics: Conference Series, 1783(1). https://doi.org/10.1088/17426596/1783/1/012105 
Purnama, I., Hartono, Y., \& Pratiwi, W. D. (2021). On Mathematical Literacy of Lower Secondary School Students in Palembang Through Problem-Based Learning. Advances in Social Science, Education and Humanities Research, 513, 621-628. https://doi.org/10.2991/assehr.k.201 230.172

Putz, L. M., Hofbauer, F., \& Treiblmaier, H. (2020). Can gamification help to improve education? Findings from a longitudinal study. Computers in Human Behavior, 110(March), 106392. https://doi.org/10.1016/j.chb.2020.1 06392

Runnalls, C., \& Hong, D. S. (2020). "Well, they understand the concept of area": pre-service teachers' responses to student area misconceptions. Mathematics Education Research Journal, 32(4), 629-651. https://doi.org/10.1007/s13394-01900274-1

Suciati, Munadi, S., Sugiman, \& Febriyanti, W. D. R. (2020). Design and Validation of Mathematical Literacy Instruments for Assessment for Learning in Indonesia. European Journal of Educational Research, 9(2), 865-875. https://doi.org/https://doi.org/10.129 73/eu-jer.9.2.865

Tohir, M., Maswar, M., Moh, A., Saiful, S., \& Rizki Pradita, D. A. (2020). Prospective teachers' expectations of students' mathematical thinking processes in solving problems. European Journal of Educational Research, 9(4), 1735-1748. https://doi.org/10.12973/EUJER.9.4.1735

Tong, D. H., Loc, N. P., Uyen, B. P., \& Cuong, P. H. (2020). Applying experiential learning to teaching the equation of a circle: A case study. European Journal of Educational Research, 9(1), 239-255. https://doi.org/10.12973/eujer.9.1.239

Widodo, S. A., Irfan, M., Trisniawati, T., Hidayat, W., Perbowo, K. S., Noto, M. S., \& Prahmana, R. C. I. (2020). Process of algebra problem-solving in formal student. Journal of Physics: Conference Series, 1657(1). https://doi.org/10.1088/17426596/1657/1/012092

Zamnah, L. N., Zaenuri, Wardono, \& Sukestiyarno. (2021). Make questions as a stimulus for students to help them carry out their Polya's step in solving problems. Journal of Physics: Conference Series, 1918(4). https://doi.org/10.1088/17426596/1918/4/042099 